\title{
Traditional Embroidery as a Method of Decoration in Najd Desert Tribes
}

\author{
Tahani Nassar Alajaji* \\ Princess Nourah Bint Abdulrahman University, Saudi Arabia
}

*Corresponding author: Tahani Nassar Alajaji, Associate Professor History of Clothing and Embroidery, College of Art and Design, Fashion and Textile Design Department, Princess Nourah Bint Abdulrahman University, Saudi Arabia.

Received Date: November 30, 2019

Published Date: December 05, 2019

\begin{abstract}
Saudi Arabian Traditional Costumes and textiles are characterized by their variety of shapes, materials and decorative styles. The natural, geographical and climatic environment in Saudi Arabia plays a prominent role in this field. It is the traditional clothing of women that limits their identity through which one can know the area in which they live, through the decoration and embroidery on their clothes. The aim of this research is to identify some of the methods used in Traditional Costumes decoration and accessories and to reveal the aesthetics of traditional embroidery as a method of traditional Najd desert tribes. Moreover, to identify the uses of embroidery method on uniforms or fabric. The research will follow the descriptive, and one of the most important tools used in data collection is the questionnaire and the observation. Among the results is the use of embroidery in many Traditional Costumes and textiles in Najd desert tribes. The variety of stitches used, and the consistency and harmony in the colors used in the decoration of traditional dress in the selection of raw materials and yarns. The use of embroidery helps to strengthen the seamstresses and the edges of the uniform or fabric, and the similarity between some areas in the forms of decoration and colors and raw materials used, and some in the case of damage to the costume is transferred to the decoration of the new costume. The embroidery has increased the aesthetic value of the costume or textile. One of the most important recommendations is to do more studies and scientific research on the traditional decoration methods. Making use of it in the fashion and textile industry in Saudi Arabia. Support and encourage professional practitioners of traditional embroidery, and finally include the traditional embroidery of Saudi Arabia among the academic programs in the field of specialization..
\end{abstract}

Keywords: Decoration; Traditional; Embroidery; Saudi Arabia; Traditional costume; Textiles; Najd desert tribes

\section{Introduction}

Saudi Arabian Costumes and textiles are characterized by their variety of shapes, materials and decorative styles. The natural, geographical and climatic environment in Saudi Arabia plays a prominent role in this field. It is the traditional clothing [1] of women that limits their identity through which one can know the area in which they live, through the decoration and embroidery on their clothes. From being lost or forgotten because of social and economic changes as well as Bedouins settling down in villages and cities. Ahmed, et al. [2] stated that there is a close relationship between the natural environment and the climatic and geographical conditions of the human life, where the human being will be affected by all such factors. The Bedouin dress is characterized by simplicity and wideness looseness, as he wears a long apparel (Thobe), head dress (kaffieh), headband and a cloak made of wool and some wealthy people may add a jacket. The cloak has an important role for the Bedouin, which can use it to protect him against winter cool weather, lays it under his head as a pillow during summer and can carry inside his necessary personal things. Hmami H [3] stated that the Bedouin dresses are long, wide and protruding to let pass a stream of fresh air, and because of their looseness they can help him get rid of the trapped drops of sand. These dresses are best fit to the Bedouin nature and mobility. Alajaji [4] described the Rolla tribes dresses as simple to better suit the quick mobility and the hot climatic condition. " the dark cloak" worn by the Bedouins in Sinai desert absorbs the extra heat before touching the skin. In Palestine desert the Bedouin woman puts on loose gown to imitate the nature of the environment where she lives as she is familiar with the vast desert [5].

Sidqi M [6] stated that the dark color of dress in the Desert absorbs the winter heat, and to avoid the burning summer heat, the parts exposed to direct Sunlight are embroidered. The Bedouin woman covers her face with a veil, or mask in order to protect her face against weather conditions and winds. She also added some silver coins to the bottom part of the veil so as not to fly while the 
wind is blowing. Salwa M [7] stated that the Bedouin woman is known for wearing a veil due to the harsh desert conditions and to protect her skin against summer heat and winter cool. Mozl A [8] disclosed that from the dress worn by the Bedouin you can tell which tribe and clan he belongs to.

Laila F [9] stated that the styles and features of ornamentation are considered as inherited customs, where you can find a difference between one gown and the other within the same tribe in Hejaz district is very minimal, however each tribe has its own features of dress decoration which makes it easier to attribute the dress to a certain tribe. The aim of this research is to identify some of the methods used in traditional Costumes decoration and accessories and to reveal the aesthetics of traditional embroidery as a method of traditional Saudi Arabia. Moreover, to identify the uses of embroidery method on uniforms or fabric.

\section{Literature}

The decoration of Costumes in Arab countries is basically made by means of embroidery [10]. Embroidery is the handicraft of decorating fabric or other materials with needle and thread or yarn. Embroidery may also incorporate other materials such as metal strips, pearls, beads, quills, and sequins. Embroidery is most often used on caps, hats, coats, blankets, dress shirts, denim, and stockings . Embroidery is available with a wide variety of thread or yarn color. An interesting characteristic of embroidery is that the basic techniques or stitches on surviving examples of the earliest embroidery ,chain stitch, buttonhole or blanket stitch, running stitch, satin stitch, cross stitch, remain the fundamental techniques of hand embroidery today [11]. Embroidery has a great importance in traditional costumes, in particular in the fabrics worn during certain occasions and functions, where embroidery is made in the prominent parts of the dress and embroidery is generally concentrated around the neck opening, on the chest and sleeves. Sometimes, on certain stitches the ornamental units are spread over the dress [12], and this is considered to be among the key styles of adornment which are widely used in the dress because it combines both aesthetical and beneficial attributes and the availability of its materials [13]. Embroidery constitutes one of the main activities of the Bedouin woman in the Arab Peninsula for fabrics and many types of furniture [10]. The embroidery art is known in all of the Kingdom's regions, where embroidery is considered as the key feature of traditional dress in Hejaz Bedouin area. In this type of embroidery most modern ways of stitching are used in addition to the stitches which have not been in use before [11]. Most tribes use many stitches in finishing and strengthening of edges, holes, extension and fixation. But in the northern region desert embroidery is known as inscription [4]. Khoqeir R [17] stated that handiwork embroidery used by Harb tribe in adornment of fabrics, accessories and other artifacts and the embroidery used in the fabrics and their accessories are most in a form of geometrical shapes, plant shapes and symbolic shapes such as the crescent.

Bean stitch is the parts added to the dress while or after being made which will be fixed to the dress for the purpose of ornamenting and matching the dress in terms of shape, color and material. The types and shapes of used freckles in the traditional fabrics and needlework are multiple, including: the type made of thread such the ones made of cord threads, others are made of metals such as purls, and plate (tally) [4,14,11] Albassam [14] stated that " black filet", is the type of decoration cut in a triangular shape fixed on the trousers foot. Buttons were used for ornamenting traditional fabrics and needlework in different sizes. Pinoll A [10] asserted that special occasions dresses in Arab countries are decorated by means of buttons, precious stones and silver balls.

Beads are not greatly different in shapes in Arab countries by their names are changed from one country to another [10]. They are various types of beads including glass beads, metal beads, wooden beads and beads made of sea materials such as snails, shells, pearl and coral stone. The amount of used beads is different from one country to another, where they are used in small quantities for woman garments at Najd, but among Altayef, Hejaz and Asser and surrounding village tribes and all Bedouins settled in Qahtan and Beni Shaheer regions, used beads in bigger quantities on fabrics and in some case will be added to embroidery. They were also sued in dress accessories and beads work [15]. Readymade beads for woman dress adornment were known for their use for woman dress within Rashayda tribe in Hejaz region [16].

Fringes is a type of ornaments of fabrics and carpets with various shapes, it is merely remains of the wrap end used in the fabrics situated outside the ornaments [12]. Albassam, et al. [15] indicated that woman in the traditional society is keen to make the piece finishing with fringes, especially head cover and belts.

Tassels is a type of decoration used for ornamenting dresses and different needle works. It is a mass of threads folded in the middle of $10-15 \mathrm{~cm}$ length after folding, then wrapped around the thread string until threads come together to form a mass. The Tassels are normally fixed on the outer edges, bags, and some head covers [12], as well as in making beads works in the Kingdom's regions. Woolen, silk, cotton and leather and beads straps are used [15]. Fada L [9] stated that all Hejaz tribes used $m$ Tassels made of cotton threads in the decoration of face veils [16].

Patching is a method of where rags of different fabrics are connected together with various embroidery beads [13] and they are manually connected or by sewing machine. Patching is one of the main features of Harb tribe woman dress in the western region of the Kingdom [17]. It is known at the northern desert of the Kingdom by the names of "Tawayer", Hathawi" or "Rawathei” [4].

Applique literally means "to put on" in French and is a technique used to decorate the surface of fabric by applying pieces of cut fabric on top of a layer of background fabric by sewing or embroidering around the edges [12,17]. Nasser S [17] indicated that using applique is used all over the countries but there are some differences from one country to another. Al-Aql [13] justified the wide spread of applique technique for the shortage of fabrics in different offers and little quantities. Applique was used by some tribes in Hejaz [18,19]. 
That woven fabric is formed of longitudinal threads known as "wrap" intersecting with transversal threads known as "weft". By the different movements of this intersection the appearance of fabrics is changed which is known as weaving formulas. The "woven ornaments" are fabric decorations woven within the fabric while processing. Harb tribe in Hejaz used this method of woven ornaments [17] and some dresses made by woven decorations known in the northern desert of the Kingdom are called "maqroona" and "zaboon" [4].

Dying, the first human used to die and engrave his body and home with pictures and symbols, and when he used clothes, he started to decorate them by using natural dies he obtained from the surrounding environment. Dying is the process of coloring tissues, threads or fabrics with natural or artificial dies (synthetic or processed). Fabrics, threads and textiles dying to add beautiful colors, has been known in all Kingdom regions [20].

\section{Research Methodology}

This research adopts a historical and descriptive method. The descriptive method studies the past phenomena by relating them to their remote origins, as it describes them and note down their developments and analyze and describe the same in order to help understand the past so as to make use of it in the present and in future. The descriptive methods is based on describing the phenomena as well as all data thereof and classify and organize such information and express the same qualitatively and quantitatively so that the researcher can arrive to deductions and generalizations to help in understanding the development of the reality which we study.

The Saudi Najd Bedouin [21] represents the original community target of the selected sample, including some itinerant nomadic tribes. Selected sample of those who have the capability to achieve the study objective among those who happened to use, see or acquire embroidered objects and dresses at Najd Bedouin area. Material Sample a set of embroidered objects and dresses at Najd desert. In information gathering, the research study depends on collecting information from the field, the tools of gathering information included: questionnaire, has been designed to investigate every piece of information concerning dresses and traditional embroideries, styles of ornaments, personal interview, observation, organized reporting of data and information via notes recording, audio recording during personal interviews, digital photography and videos were taken. The scientific benefit of the research is to attain accurate information and facts not previously attained in this type of research. Therefore, the researcher is required to add to human knowledge. In this research a number of traditional embroidered dresses have been collected, as well as samples exhibiting the method of making traditional stitching and embroidered motives, jotting down the same as well as making demonstrative drawings and then developing some styles in order to keep pace with the modern era requirements without undermining the traditional touches while making modern dresses to fit the current modern life style.

\section{Results and Discussion}

\section{Embroiderey patterns in Najd desert}

Embroidery: Traditional clothes are distinguished by using various decorating methods and techniques, the most important being embroidery also known as pattern or models among tribes. Embroideries change its shape, name, and place among tribes. Regarding embroidered items such as bed sheets, the most important stitch used is Hasirah Ajamiah Stitch, which is also known as filler (hasho) among Bedouins. Some of the stitches used in the Najd desert are [22]:

1. Basket Stitch: it is used in decorating bed sheets, pillow covers, dresses, and trousers. Two methods are used in doing this stitch.

2. Issam Stitch: it is used to connect and sew woolen and leather pieces together and to finish and strengthen the openings in embroidered items or clothes (Figure 1).

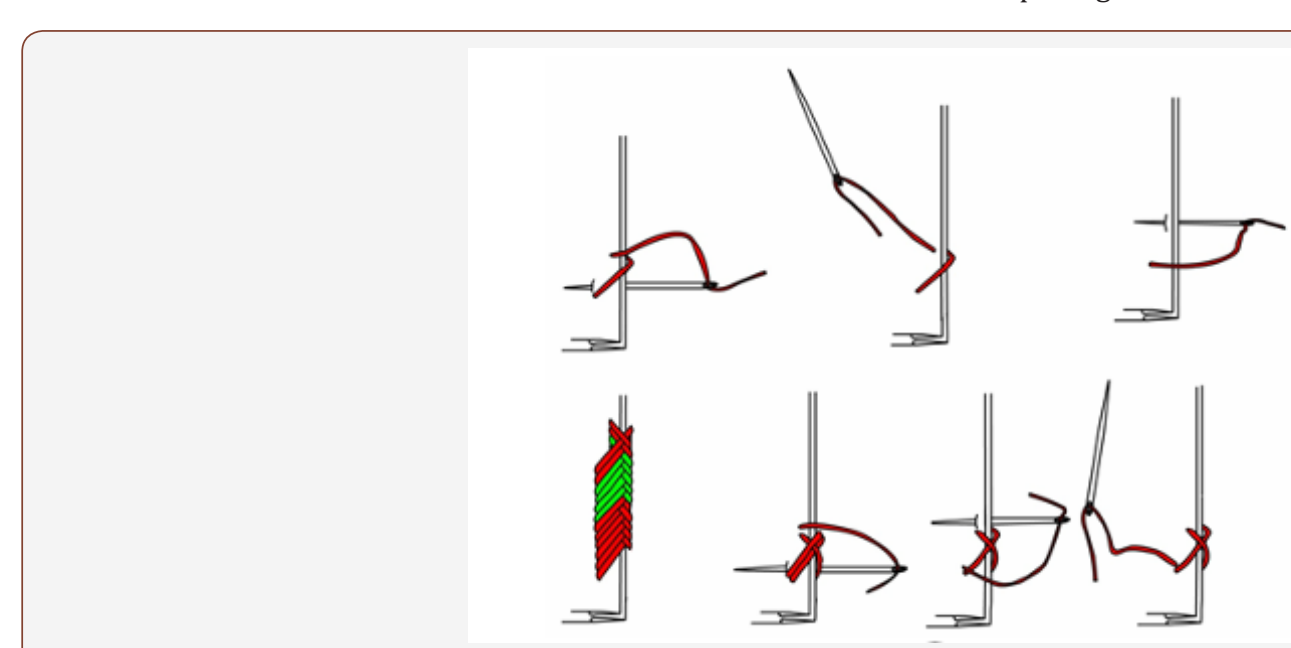

Figure 1: Steps to implement the Issam stitch.

3. Tabreek Stitch: it is used to finish and strengthen openings of woolen bags such as Qatf and Mazwadah. It requires using two needles and is not mentioned in embroidery books (Figure 2). 

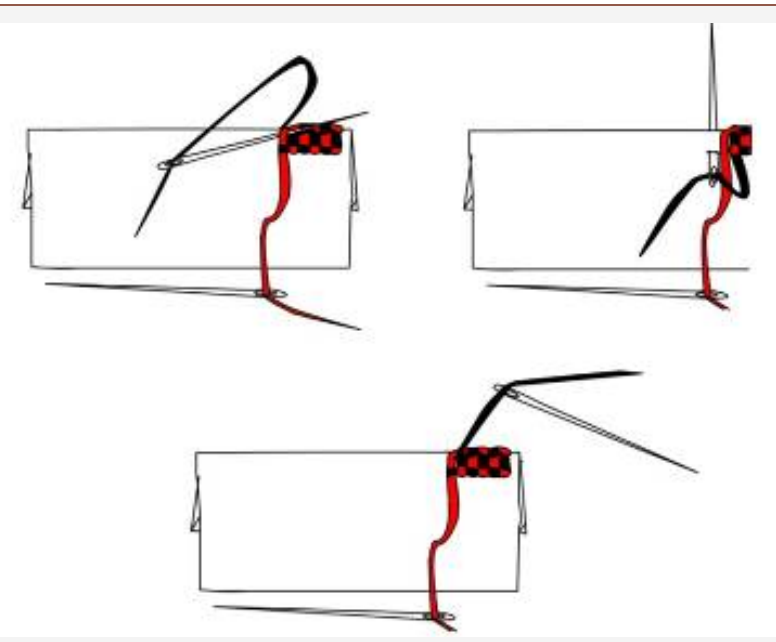

Figure 2: Steps to implement Altberak stitch.

4. Shadeed (Nathra) stitch: it is a cross stitch on a straight line and is used in decorating and embroidering women and men clothes (Figure 3).

5. Stretching and strengthening using Fastoun stitch: it is used in an innovative manner not mentioned in embroidery books. It consists of creating several parallel rows on the edge of the sleeves, with Fastoun stitch used as filler threads to cover the parallel rows on the edges. The first row shall be on the edge of the sleeve. This stitch can be done using different colors such as red, green, or yellow. One row of this stitch can be used around the collar opening (Figure 4).
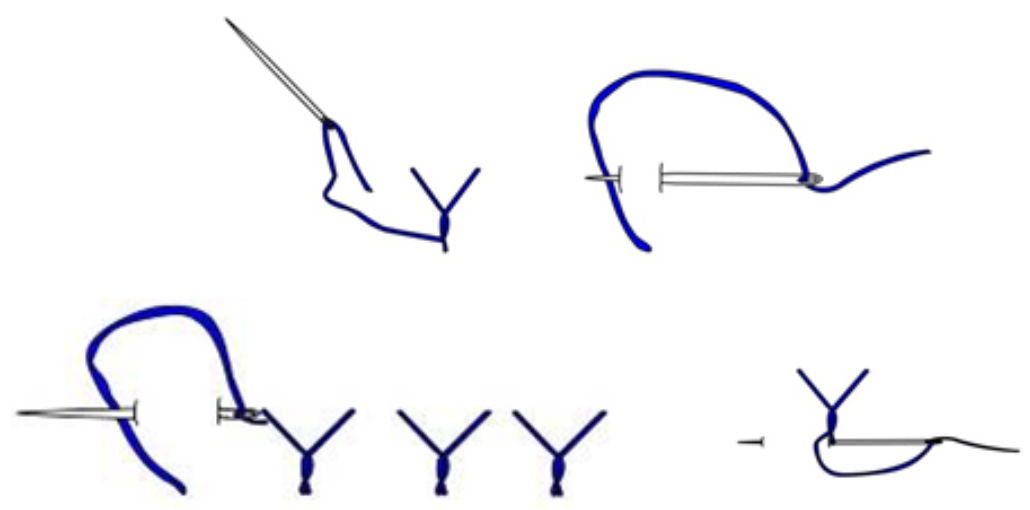

Figure 3: Steps to implement Shadeed (Nathra) stitch.

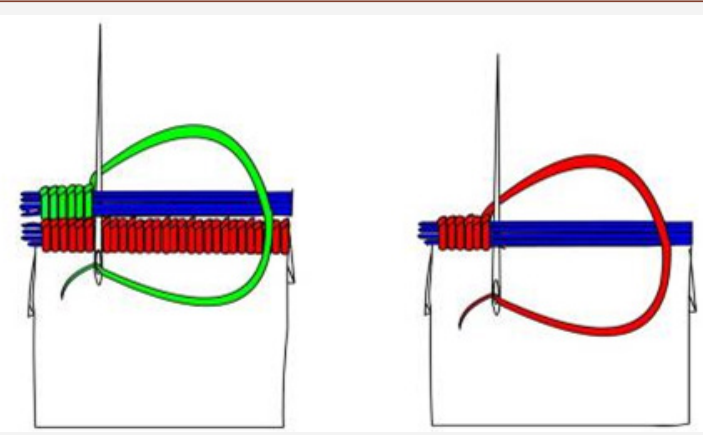

Figure 4: Steps to implement stretching and strengthening using Fastoun stitch.

\section{Wool and added materials}

1. Braided stitch: It is used in decorating and finishing the edges of some clothes and other traditional items such as Baksheh (bag), Mazwadeh (bag used for carrying food), Makhaleh (bag used to gather makeup items), Bedouin cushions, Mizbaa, Hawdaj (carriage that is on back of camels), and Igal (rope that is worn in head). This stitch is used by all tribes and has two ways in braiding:

2. Tassels: It is used to decorate and finish the edges of some clothes and items.

3. Thread wrapping: It is used in some items and clothes such as head scarfs, Igal (head rope), bandana, and so on (Figure 5). 

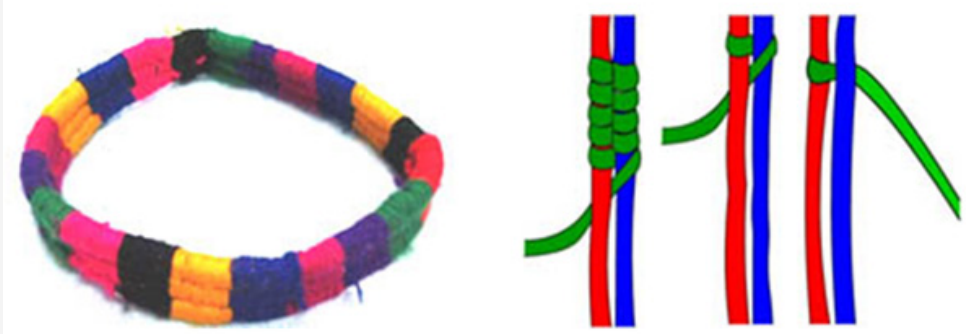

Figure 5: Thread wrapping

4. Applique and Patch work: It is adding small or mediumsized patches of textiles onto a larger area with different color or material or both by sewing it using needle or machine embroidery stitches. It is used extensively in decorating textiles such as bed sheets, Hodag, trousers, thob (traditional dress), and mokataa. Patch work is also used in decorating textiles and clothes as it is manually sewed or by machine sewing pieces of clothes of different materials or colors.

5. Threads: It is either material threads (golden or silver color) or cotton threads and the choice depend on the type of custom, textile, and occasion. Threads are used extensively in zaboon, sayieh, turbans, and cloak.

6. Shells: It is used to decorate some head scarfs and embroidered items such as mirror cover.

7. Zippers: Some of the Bedouin tribes especially Kahitan use zippers in decorating women head scarves such as the bandana (issaaba) where the zipper is separated into two pieces and then each piece sewed as the decorating edge.
Knitting: It is used in making hats and socks and is well known in the Shamar tribe only where a man knits woven threads of camel's hair using wooden sticks. The wooden sticks have been replaced by locally made needle, which is similar to the knitting needle. Currently, such work is not needed and if required is done by girls in the tribe who are responsible for producing pieces made of woolen threads as hand protectors for kettles, children clothes, covers, and so on.

Dyeing: The Bedouin women dye used threads in decorating textiles, costumes, and clothes such as head scarves, mokata, and mokamam.

\section{Embroidered patterns and drawings used in Najd Desert}

Nature-inspired drawings: roses, palm tree, leaves, cardamom, pigeon foot, grape vine, wheat, or fruits. Inspirations drawn from: kettles, mosque, variety of vases, basket, camel, or Al-Aqsa Mosque. Geometric patterns: zigzag, curved or straight lines, circles, squares, triangles or dots. Human and animal drawings derived from: other cultures, such as a girl wearing strange clothes or a peacock (Figures 6\&7).

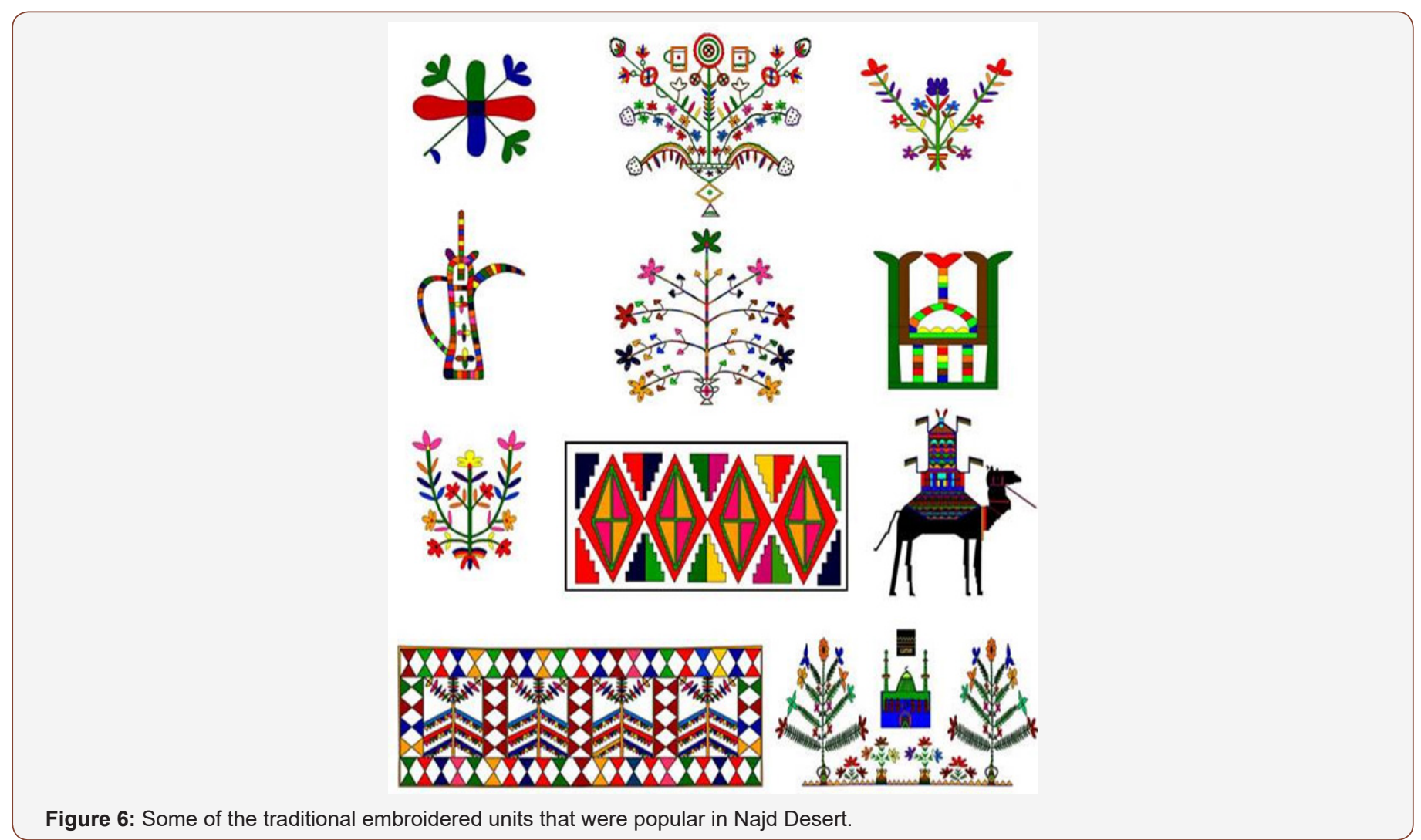



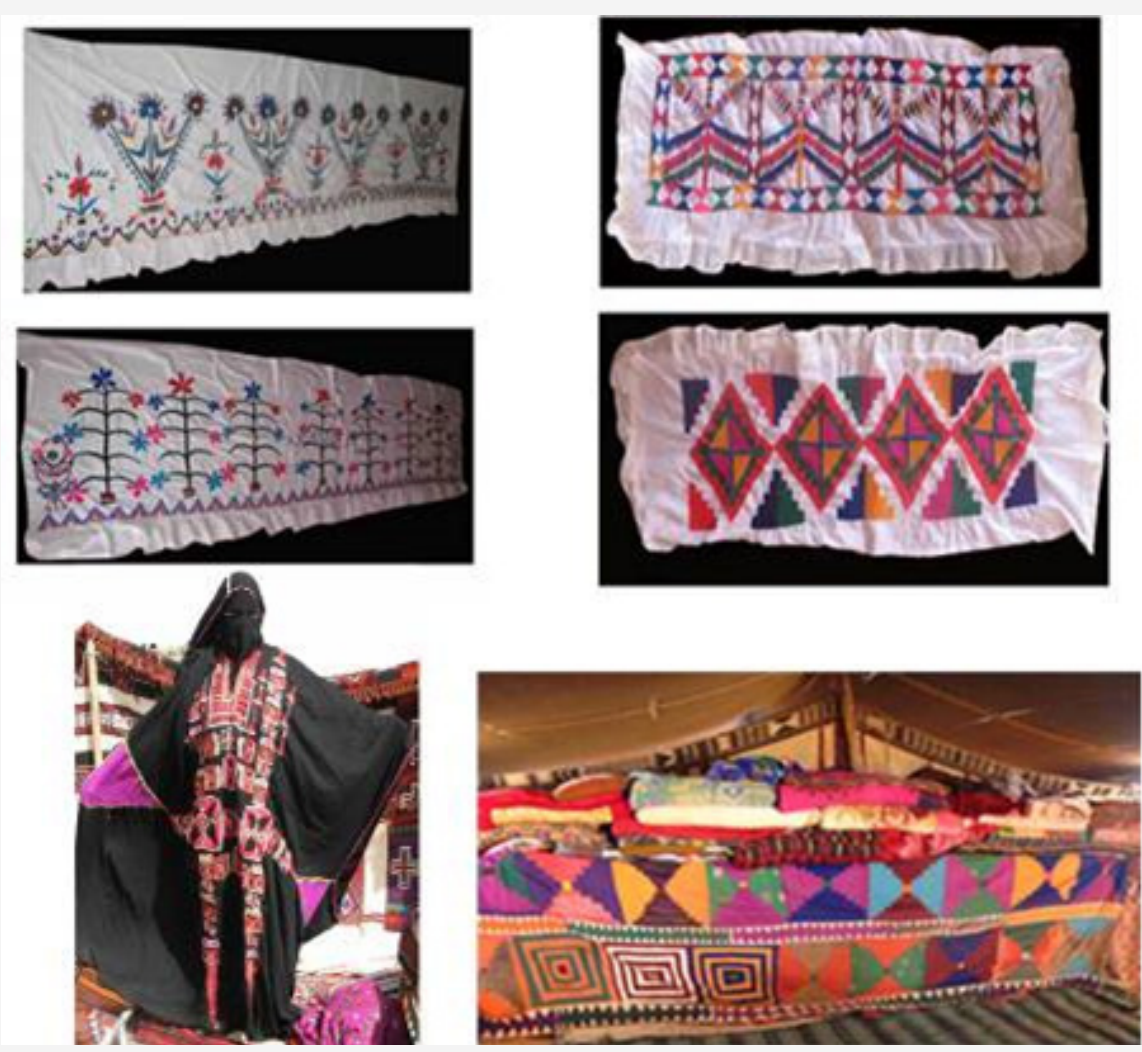

Figure 7: Some of costumes and embroidered handcrafts of Najd desert tribes.

The basic motivations behind embroidering costumes and other items

Beautifying traditional clothes and items. Connecting some clothes with leather and woolen pieces. Finishing and strengthening openings in items or costumes. Mimicking the environment by using drawing inspired from surrounding environment in embroidered costumes and items [4]. Influence of different cultures because of movement and communication with such cultures, appearance of foreign drawings such as human and animal drawings, wearing strange costumes, and arranging roses in different ways that is, using a vase or pots. Restricted number of desert costume colors resulted in using different colored threads in embroidery works. Spending time during shepherding or otherwise doing embroidery works.

\section{Practical Applications of Traditional Decoration at Najd Nomadic Area}

Some modern dresses and accessories have been implemented in order to make use of what has been collected during the research work, such as pictures, decoration of dresses and embroidered traditional works at Najd nomadic area. This has been made by making some decorated designs inspired from traditional ornaments and development of some methods and materials suiting the modern era requirements without undermining the traditional norm of this art. This is intended to help the Bedouin woman to develop what it can be developed so that she can make use of her traditional handicrafts for modern lifestyle. Some designs were implemented and applied. Here below are some of such applications (Figures 8-11):
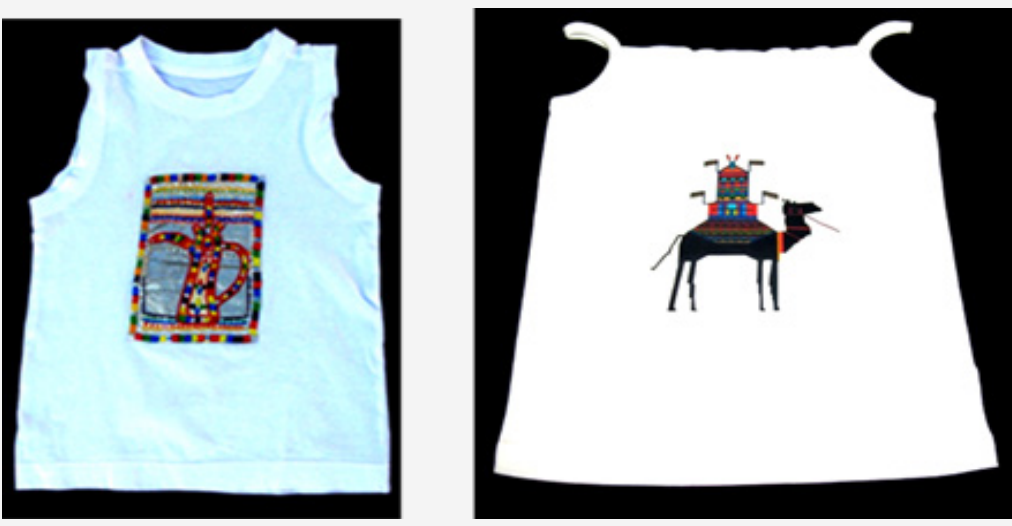

Figure 8: Two shirts decorated with traditional motives: a camel equipped with saddle, the first shirt decorated by printing style, the shirt decorated with a printed picture of coffee pot, the chain and the saddle decorated with cotton and metal strings and silver sequins and the background of the design is printed in silver color. 

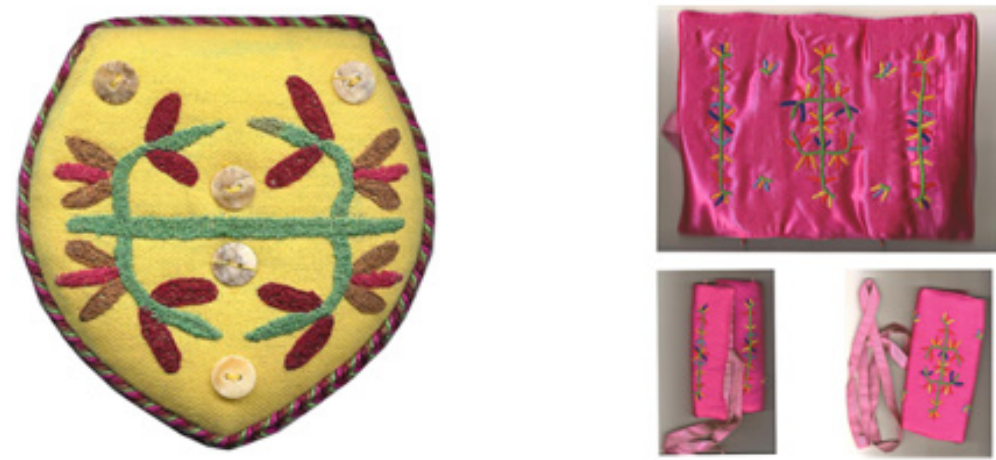

Figure 9: Jewelry purse decorated with a traditional motive using Roumainian stitching, mirror box decorated with Bedouin traditional motives using mat stitch and buttons whose outer edges are decorated with strand (elephant tale).
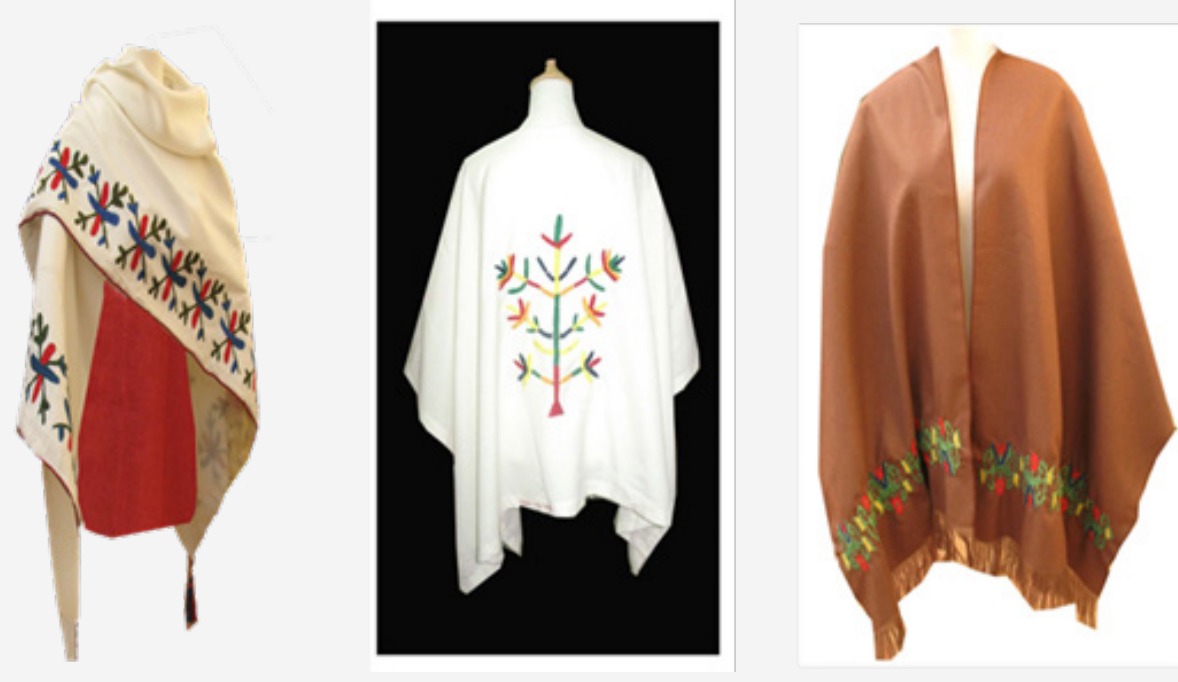

Figure 10: Shawls made of cotton and wool fabrics embroidered with traditional Bedouin motives, with Roumainian stitch using silk, metal threads and sequins.
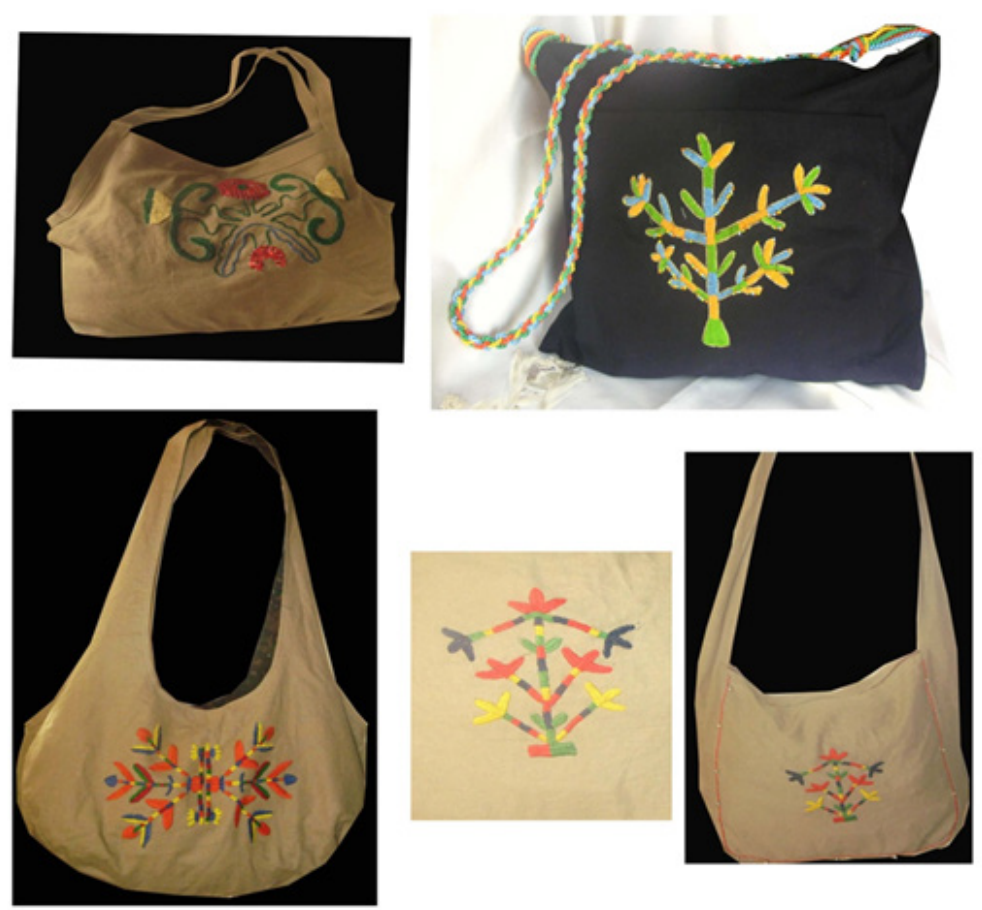

Figure 10: A set of bags decorated with traditional Bedouin motives, embroidered using Roumainian stitch with silk threads and metallic sequins. 


\section{Conclusion}

The study proved the importance of exhibiting traditional decorations through their use in dress and accessories designs and the attempt to reshape the same in a new innovative shape so as to preserve them against vanishing. Make use of distinguished ornaments of dress and traditional needle works at Najd desert in the manufacture of dresses and accessories as well as encouraging preservers of folklore and handicrafts persons and provide them support as well as creating new opportunities for them in the new lifestyle spheres. Designing dresses and their components by means of using traditional ornaments available at Najd desert to make them distinguished from imported ones. Making decorated designs inspired from traditional ornaments and development of some styles and materials suiting the needs of current era without undermining the traditional nature of the same. The diversity of traditional decorations has helped in exhibiting the designs of dress and accessories in a manner that distinguish them from those offered in the local market.

One of the most important recommendations is to do more studies and scientific research on the traditional decoration methods. Making use of it in the fashion and textile industry in Saudi Arabia. Support and encourage professional practitioners of traditional embroidery, the traditional embroidery of Saudi Arabia among the academic programs in the field of specialization, and finally include Assist the Bedouin woman in developing what can be developed in order to utilize her traditional arts and handicrafts in her current era life.

\section{Acknowledgement}

None.

\section{Conflict of Interest}

Author declare no conflict of interest.

\section{References}

1. Laila A, Mona S (1999) Similarity of women's clothing popular in the Arab world, the outlook for the domestic economy and the challenges of the twenty-first century in the Environmental Protection and Community Development, University of Alexandria, Alexandria.

2. Kfaah AS, Zidane, Said Y, Hanan (2010) Popular fashion between restoration and tradition, Riyadh: Dar al-Zahra, Saudi Arabia.

3. Hassan H (1972) popular costumes and traditions in Syria, Damascus: Publications of the Ministry of Culture.
4. Tahani A (2005) Traditional Women's Costumes of The Northern Region of Saudi Arabia "field study". Riyadh, Saudi Arabia.

5. Laila A, Mona S (1999) Methods of Bedouin costumes decorated with a comparative study between Egypt and Saudi Arabia, the first symposium of the domestic economy, King Abdul Aziz University, Jeddah, Saudi Arabia.

6. Sidqi M (1989) Study of the factors influencing popular traditional costumes excellence to the North Sinai Bedouin, Ph.D. thesis, University of Helwan College of Home Economics.

7. Salwa M (1986) The short encyclopedia of fashion, jewelry and ornamental folk in Kuwait. Kuwait.

8. Mozl A (1997) Rolla manners and customs, ( $2^{\text {nd }}$ edn), Riyadh: repentance library.

9. Fada L (2003) The traditional methods of garment decoration for women in the Hijaz comparative study, Ph.D. thesis, Faculty of Home Economics and Art Education, Riyadh, Saudi Arabia.

10. Pinoll A (1997) Adornment in the Arab world. Beirut: Prints.

11. Fada L (1993) traditional clothing for women in Mecca methods and Ttrisaha of field study, Master Thesis, Faculty of Education, Home Economics and Art Education, Riyadh, Saudi Arabia.

12. Al-Hlal, Naglaa (2003) Patchwork and Alablak. Riyadh: Dar lsoltah.

13. Al-Aql W (2005) Develop methods of decorating the traditional clothing of women in Saudi Arabia. Riyadh , Saudi Arabia.

14. Laila A (1985) The traditional heritage of women's clothing in Najd, Doha: Folklore Center Gulf Arab states.

15. Laila A, Mona S (2000) Craft traditional beads in the Kingdom of Saudi Arabia. Journal of popular traditions Issue 58: 7-37.

16. Fada L (2008) Traditional clothing for women tribe Rashayidah, popular culture magazine, Third Issue: $160-173$.

17. Nasser S (2000) The embroidered fabric in the Ottoman era. Cairo: the world of books, Egypt.

18. Fada L (2003) The traditional methods of garment decoration for women in the Hijaz comparative study, Ph.D. thesis, Faculty of Home Economics and Art Education, Riyadh, Saudi Arabia.

19. Fada L (2008) Traditional clothing for women tribe Rashayidah, popular culture magazine, Third Issue: 160 -173.

20. AL-Mutairi, Mohammed S (2003) Study of traditional textiles and preservation methods and documented, Ph.D. thesis, Faculty of Home Economics and Art Education, Riyadh, Saudi Arabia.

21. Tahani A (2011) Bedouin Traditional Costumes and Embroidered Crafts in Najd, Saudi Arabia.

22. Laila A (1988) Methods and motifs in traditional clothes in Najd. A field study comparison between men's wear and women, Riyadh, Saudi Arabia. 